\title{
A Study on Customer Satisfaction towards Car Proprietors in Theni Town
}

\author{
${ }^{1}$ M. DIVYA DEVI, ${ }^{2}$ Dr. S.CHITRA \\ ${ }^{1}$ M.Phil Scholar, ${ }^{2}$ Principal \& Professor, Department of commerce, Nadar Saraswathi College of \\ arts \& science, Theni, India.
}

\begin{abstract}
Satisfaction is crucial concern for both customers and organizations. Satisfaction is a subjective concept and therefore difficult to determine. It depends on many factors and varies from person to person and product to product. The importance of customer satisfaction in strategy development for customers and market oriented cannot be underdetermined. Now a day it has become very important factor for each and every organization to enhance the level of customer satisfaction. The overall study reveals that it was found that the customer are mostly satisfied with price , design, safety, mileage, status brand name, comfort level, Mode of purchase and after sale service.
\end{abstract}

KEYWORDS - Car proprietor satisfaction, Mileage, Car models.

\section{INTRODUCTION}

Increase in Income Level, Decline in Tax and interest rates have helped to increase in personal disposable income. Change in Mindset leading to changing investment, spending pattern from property investment to increasing consumerism and explosive growth in communication have led to urbanization of Rural consumer's attitude and has increased the Propensity to consume.

\section{REVIEW LITERATURE}

Following are the some of the review of literature to analyses scientific works by other researchers that aims to review the critical points of current knowledge including substantive findings as well as theoretical and methodological contributions:

* Arpita srivastava and et.al. (2014) in his study on consumer behaviour towards passengers Cars in Delhi found that the most important factor that influences the consumer to use passenger car is the price of the cars, social status and durability. They concluded that Customers are purchasing the cars not only as a means of transport but as a status symbol also.

* Clement Sudhakar and et.al. (2009) studied the Influence of peer group in the purchase of car with reference to Theni. It was found that the influence of friends is higher for the purchase of small sized and midsized cars.

* Joseph and Richard emphasized the known fact that brand loyalty emerges from brand satisfaction. They observed that a relatively strong relationship existed between brand loyalty and satisfaction with a present product of that brand.

* The approach of Edgar A Pessenier (1959) on brand switching behaviour was based on the price factor. He emphasized the fact that price increase in the most preferred brand relative to the price of the other brands, is essential to introduce brand switching behaviour among Customers.

* Brand attitudes and usage level vary for different brands. The relationship between the attitudinal change and behavioural change with regard to the same group of people was analyzed and studied by channon and Ehrenberg.

\section{RESEARCH METHODOLOGY}

Research methodology is a way to systematically solve the research problems. It may be understood as a science of studying how research is done scientifically. Primary data collected from Theni town. A sample size of 250 respondents has been under taken through judgment sampling method.

\section{RESEARCH OBJECTIVES}

The objective of the study is to evaluate car owners to the purchase and use of cars and their satisfaction. The specific objectives of the study are:

* To know about the automobile industry.

* To provide the personal details of sample respondents and to assess their usage of cars.

* To analyze the factors influencing the buying behaviour of car proprietors.

* To identify the factors influencing the customers satisfaction.

* To offer the suggestions based on the findings of the study.

TOOLS FOR THE STUDY
$\quad$ Percentage
$\quad$ Chi square test
$\quad$ Garrett Rank
$\quad$ Likert Scale
ANOVA - Two Way method




\section{PERCENTAGE}

TABLE NO: 1 PROFILE OF THE RESPONDENTS

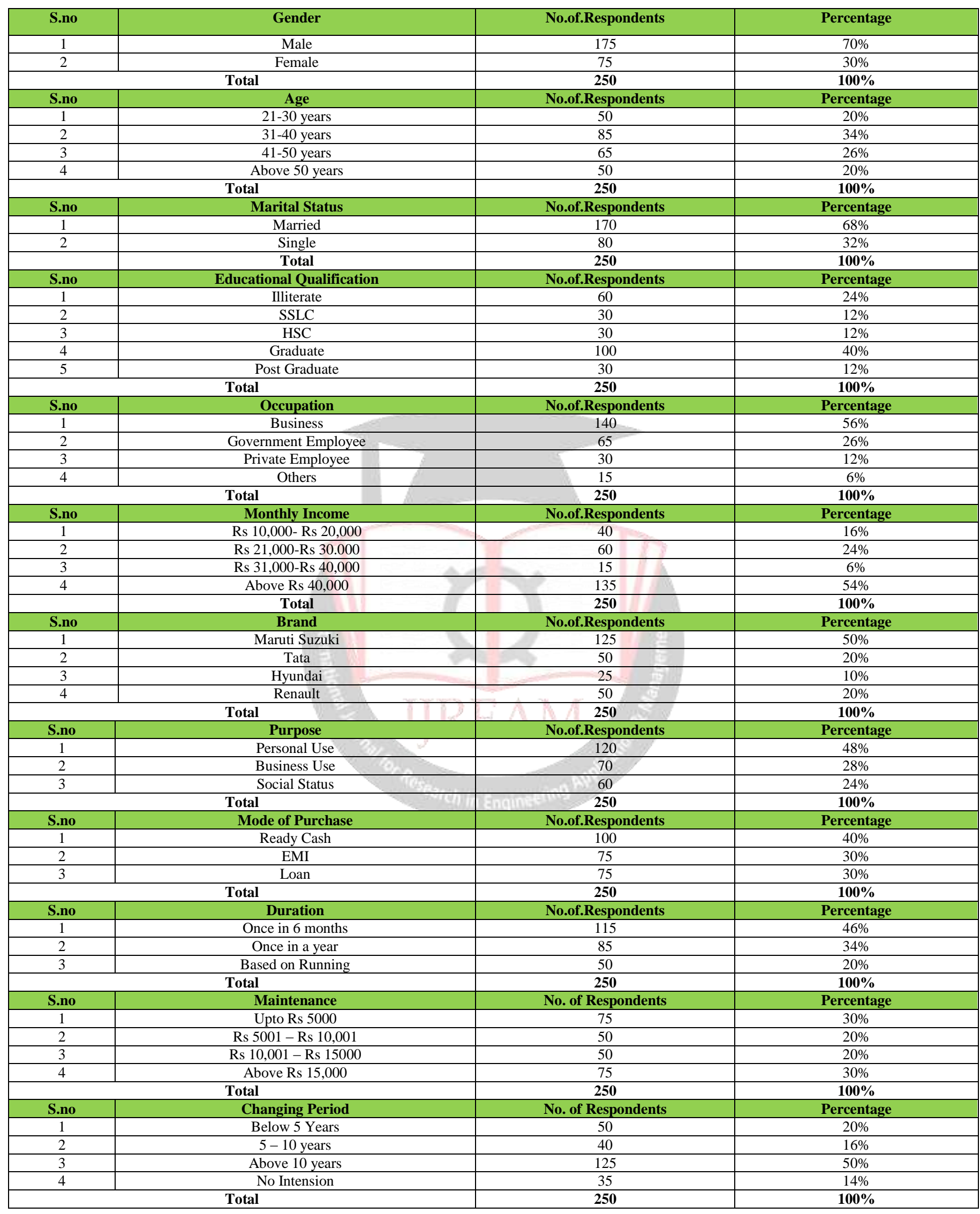

\section{CHI SQUARE TEST}


TABLE NO: 2 GENDER OF THE RESPONDENTS AND THEIR LEVEL OF SATISFACTION

\begin{tabular}{|c|l|c|c|c|c|}
\hline \multirow{2}{*}{ S.No } & \multirow{2}{*}{ Gender } & \multicolumn{3}{|c|}{ Number of the respondents } & \multirow{2}{*}{ Total } \\
\cline { 3 - 6 } & & High & Medium & 45 & \\
\hline 1. & Male & 45 & 85 & 5 & $\mathbf{1 7 5}$ \\
\hline 2. & Female & 45 & 25 & $\mathbf{5 0}$ & $\mathbf{7 5}$ \\
\hline
\end{tabular}

(Source: Computed data)

"Gender of the respondents does not have significant relationship with the level of satisfaction of the respondents towards customer satisfaction of car proprietors" is rejected.

MONTHLY INCOME WISE CLASSIFICATION OF THE RESPONDENT

TABLE NO: 3 MONTHLY INCOME OF THE RESPONDENTS AND THEIR LEVEL OF SATISFACTION

\begin{tabular}{|c|c|c|c|c|c|}
\hline \multirow{2}{*}{ S.No } & \multirow{2}{*}{ Monthly Income } & \multicolumn{3}{|c|}{ Number of respondents } & \multirow{2}{*}{ Total } \\
\hline & & High & Medium & Low & \\
\hline 1. & Rs 10,000 - Rs 20,000 & 70 & 35 & 30 & 135 \\
\hline 2. & Rs $21,000-$ Rs 30.000 & 5 & 40 & 15 & 60 \\
\hline 3. & Rs $31,000-R s$ 40,000 & - & 15 & - & 15 \\
\hline 4. & Above Rs 40,000 & 15 & 20 & 5 & 40 \\
\hline & Total & 90 & 110 & $\mathbf{5 0}$ & 250 \\
\hline
\end{tabular}

(Source: computed data)

"Monthly income of the respondents does not have significant relationship with the level of satisfaction of respondents towards customer satisfaction of car proprietors" is accepted.

\section{GARRETT RANK}

The customer like some factor while choosing the car for the purpose of purchase of car. To analyze this factor, Garrett Ranking method is applied. As per this method respondents have been asked to consign the rank for all factors and the outcome of such ranking has been converted into score value with the help of following formula:

Percent position $=100(\mathrm{Rij}-0.5) / \mathrm{Nj}$

Where,

Rij= Rank given for the $i^{\text {th }}$ variable by $j^{\text {th }}$ respondents

$\mathrm{Nj}=$ Number of variable ranked by $\mathrm{j}^{\text {th }}$ respondents

TABLE NO: 4 PROBLEMS FACED BY THE CUSTOMER IN CAR PROPRIETORS

\begin{tabular}{|c|c|c|c|c|c|c|c|c|c|c|}
\hline \multicolumn{2}{|c|}{ Rank } & 1 & 2 & 3 & 4 & 5 & 6 & 7 & 8 & Total \\
\hline \multicolumn{2}{|c|}{ Score } & 79 & 68 & 60 & 53 & 47 & 41 & 32 & 20 & $\sum \mathbf{f} \mathbf{x}$ \\
\hline \multirow[t]{2}{*}{ F1 } & $\mathbf{F}$ & 105 & 70 & 15 & 25 & 10 & 0 & 10 & 15 & \multirow[b]{2}{*}{16370} \\
\hline & $\mathbf{f x}$ & 8295 & 4760 & 900 & 1325 & 470 & 0 & 320 & 300 & \\
\hline \multirow[t]{2}{*}{ F2 } & $\mathbf{F}$ & 35 & 55 & 55 & 30 & 10 & 15 & 25 & 25 & \multirow[b]{2}{*}{13780} \\
\hline & $\mathbf{f x}$ & 2765 & 3740 & 3300 & 1590 & 470 & 615 & 800 & 500 & \\
\hline \multirow[t]{2}{*}{ F3 } & f & 10 & 20 & 10 & 65 & 55 & 55 & 10 & 25 & \multirow[b]{2}{*}{11855} \\
\hline & $f x$ & 790 & 1360 & 600 & 3445 & 2585 & 2255 & 320 & 500 & \\
\hline \multirow[t]{2}{*}{ F4 } & f & 20 & 5 & 15 & 25 & 30 & 50 & 60 & 45 & \multirow[b]{2}{*}{10425} \\
\hline & $\mathbf{f x}$ & 1580 & 340 & 900 & 1325 & 1410 & 2050 & 1920 & 900 & \\
\hline \multirow[t]{2}{*}{ F5 } & $\mathbf{f}$ & 20 & 25 & 10 & 20 & 30 & 40 & 60 & 45 & \multirow{2}{*}{10810} \\
\hline & $f x$ & 1580 & 1700 & 600 & 1060 & 1410 & 1640 & 1920 & 900 & \\
\hline \multirow[t]{2}{*}{ F6 } & f & 15 & 10 & 10 & 15 & 45 & 40 & 60 & 55 & \multirow{2}{*}{10035} \\
\hline & $f x$ & 1185 & 680 & 600 & 795 & 2115 & 1640 & 1920 & 1100 & \\
\hline
\end{tabular}




\begin{tabular}{|c|c|c|c|c|c|c|c|c|c|c|}
\hline F7 & $\mathbf{f}$ & 10 & 15 & 50 & 50 & 55 & 25 & 20 & 25 & 12210 \\
\cline { 2 - 11 } & $\mathbf{f x}$ & 790 & 1020 & 3000 & 2650 & 2585 & 1025 & 640 & 500 \\
\hline F8 & $\mathbf{f}$ & 35 & 50 & 85 & 20 & 15 & 25 & 5 & 15 & 14515 \\
\cline { 2 - 11 } & $\mathbf{f x}$ & 2765 & 3400 & 5100 & 1060 & 705 & 1025 & 160 & 300 \\
\hline
\end{tabular}

\begin{tabular}{|c|c|c|c|}
\hline Factors & Total & Average Score & Rank \\
\hline F1 & $16370 / 250$ & 65.48 & I \\
\hline F2 & $13780 / 250$ & 55.12 & III \\
\hline F3 & $11855 / 250$ & 47.42 & V \\
\hline F4 & $10425 / 250$ & 41.7 & VII \\
\hline F5 & $10810 / 250$ & 43.24 & VI \\
\hline F6 & $10035 / 250$ & 40.14 & VIII \\
\hline F8 & $12210 / 250$ & 48.84 & IV \\
\hline
\end{tabular}

(Source: Computed Data)

The analysis of the first rank is given to technology for the problems are faced by the customers and their last rank is given to Insurance.

4. LIKERT SCALE

The researcher analyzed the satisfaction level towards car proprietors among the sample respondents by applying Liker's scaling technique.

TABLE NO: 5 LIKERT SCALE

\begin{tabular}{|c|c|c|c|c|c|c|c|c|}
\hline S.No & Factors & HS & $\mathbf{S}$ & $\mathbf{M}$ & DS & HDS & $\begin{array}{l}\text { Total } \\
\text { Points }\end{array}$ & Rank \\
\hline 1 & $\begin{array}{l}\text { Cost of the Vehicle is } \\
\text { Reasonable. }\end{array}$ & 875 & 160 & 30 & 10 & 0 & 1135 & I \\
\hline 2 & $\begin{array}{l}\text { Maintenance cost is } \\
\text { Affordable. }\end{array}$ & 150 & 240 & 105 & 10 & 0 & 1105 & II \\
\hline 3 & $\begin{array}{l}\text { Driving is comfortable } \\
\text { and safety. }\end{array}$ & 145 & 280 & 25 & 0 & 10 & 1090 & III \\
\hline 4 & $\begin{array}{l}\text { Spare parts are freely } \\
\text { Available }\end{array}$ & 80 & $\begin{array}{l}130 \\
520\end{array}$ & 30 & 10 & 0 & 1030 & IV \\
\hline 5 & $\begin{array}{l}\text { Dealer's service is } \\
\text { appreciated }\end{array}$ & 100 & 380 & 90 & 10 & 20 & 1000 & VI \\
\hline 6 & $\begin{array}{l}\text { Consumption of Fuel is } \\
\text { very Economical. }\end{array}$ & 95 & 360 & 135 & 30 & 5 & 1005 & $\mathrm{~V}$ \\
\hline 7 & $\begin{array}{l}\text { Latest Technology is } \\
\text { introduced. }\end{array}$ & 65 & 340 & 150 & 100 & 0 & 915 & XII \\
\hline 8 & Car is a status of symbol. & 65 & 380 & 165 & 20 & 15 & 925 & $\mathrm{X}$ \\
\hline 9 & $\begin{array}{l}\text { Insurance premium is } \\
\text { nominal. }\end{array}$ & 325 & 360 & 165 & 60 & 10 & 920 & XI \\
\hline
\end{tabular}




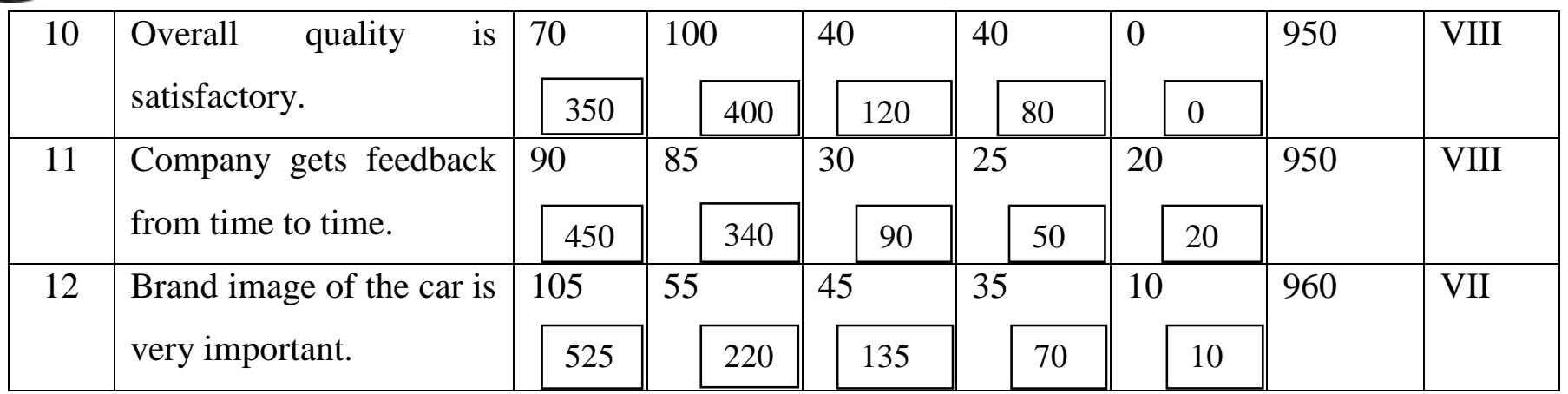

\section{(Source: Computed Data)}

The factor analysis of the cost of the vehicle is reasonable in first rank for the deciding the satisfaction level of the sample respondents and design to get least rank in Latest Technology.

\section{ANALYSIS OF VARIANCE - TWO WAY CLASSIFICATION MODEL}

Analysis of variance is used to test the effect of independent factors on response variable to interest. Let us take the hypothesis that there is no significant difference between respondents for car proprietors.

TABLE NO: 6 ANOVA TWO WAY CLASSIFICATION TABLE

\begin{tabular}{|c|c|c|c|c|}
\hline Source of Variation & Sum of squares & Degree of freedom & Mean squares & Ratio of F \\
\hline $\begin{array}{c}\text { Between columns (Purpose for } \\
\text { purchasing the car) }\end{array}$ & 538.9 & 2 & 1970.8 & 48.90 \\
\hline $\begin{array}{c}\text { Between Rows } \\
\text { (Reason for switch over the brand) }\end{array}$ & 972.2 & 2 & 486.1 & 12.06 \\
\hline Residual & 161.2 & 4 & 40.3 & \\
\hline Total & $\mathbf{1 6 7 2 . 3}$ & $\mathbf{8}$ & & \\
\hline
\end{tabular}

Purpose for Purchase the car and Reason for switch over the brand relationship between their significantly.

\section{SUGGESTION}

After observing the above findings, the researcher gives the following suggestions for the study. On the basis of the information obtained from the car owners, the researcher feels that it is his duty to offer some valuable suggestions for enhancing better customer.

The car owners perceive that driving comfort and fuel economy are the most important features of the car followed by the availability of spare parts and the price of the car. Thus manufacturers should design the car giving more importance to these factors.

- With the competition for space, cars with compact bodies which occupy lesser parking space could be given priority. The government can promote car parking lots either on its own or as a joint venture with the private sector in the major cities as in the foreign countries. It is also suggested that the manufacturers should come forward to design the cars with compact bodies.

- The demand for small car segment is increasing because of the growing number of nuclear families as well as parking problems, Therefore, the manufacturers should find out the needs, wants, tastes and preferences of the consumers in order to design the products.

Due to steady increase the price of petrol/ diesel, fuel efficiency needs to be improved. Constant improvement and technical up gradation for better fuel efficiency alone will attract and trained more customers.

The present study suggests that the brand image and loyalty could be boosted by selling quality of cars at a reasonable price to suit the needs of the middle income group.

\section{CONCLUSION}

Now a day's majority of the people depend on car for all our work whether it is small or big. Customer to take proper care and should give a complete servicing in regular time interval basis. Hence in this digital world, car is no longer a luxury. From the discussions made in the study, influencing the car purchase decision making attitudes is needs \& wants in our personal life, people accept the technology changes and more number of respondents are switch over the brand for the purpose of personal image \& prestige also. Majority of the respondents prefer the Maruti Suzuki Branded car. Because its comfortable price value, variety of models and affordable mileage etc. 
Finally, The Manufacturers should concentrate on the features of driving comfort and fuel as they may be the choice of few more prospective buyers. The researcher strongly believes that if all the suggestions are carried out by the car producer the bright future for Automobile industry. It's supporting to development for the economic welfare of the country.

\section{REFERENCES}

[1] Arpita srivastava and Mitumatta (2014) - consumer behaviour towards cars- A study in Delhi NCR, global journal of Finance and management. ISSN 0975-6477 Voulme6, Number 6 (2014), pp-589-598.

[2] Dr.P.Parasakthi and Dr.P.B.Banudevi (September 2014) - A study on consumer awareness and brand preferences towards small cars in Coimbatore district. Indian journal of Applied Research, Volume: 4, Issue: 9, September 2014, ISSN - 2249-555X, PP-75.

[3] Chidambaram and Alfred, A study on Brand preference of car with preference to Coimbatore city, Indian Journal of Marketing, Volume: 34, No: 9, September 2007, P.30.

[4] International Journal of scientific and Research publications, Volume:4, Issue:2, February 2014, ISSN:2250-3153,P.No: 7.

[5] Suresh A.M. Raja K G (2006) - Measuring customer satisfaction of car- An empirical study ", Indian journal of Marketing, February, pp: 3-8.

\section{WEBSITES}

[6] www.researchgate.net

[7] www.google.com

[8] www.wikipedia.com 